\title{
Uso do Desfibriladores externos automáticos (DEA) por pessoas leigas no atendimento Pré-hospitalar: Uma Revisão Integrativa da Literatura
}

\author{
Use of Automated External Defibrillators (AEDs) by Lay People in Prehospital Care: An
}

\author{
Integrative Literature Review
}

Uso de desfibriladores externos automáticos (DEA) por personas no profesionales en la atención prehospitalaria: Revisión integradora de la literatura

Maria de Nazaré dos Anjos Ferreira ORCID: https://orcid.org/0000-0002-4786-9497 Escola Superior da Amazônia, Brasil E-mail: mariadenazaredosanjosferreira@gmail.com

Luciana Alves Barbosa

ORCID: https://orcid.org/0000-0001-5171-5426 Escola Superior da Amazônia, Brasil E-mail: luciana.a.barbosa@hotmail.com

Marcela Raíssa Asevedo Dergan ORCID: https://orcid.org/0000-0003-1457-0242 Universidade do Estado do Pará, Brasil E-mail: derganm20@gmail.com

Paula Andreza Viana Lima

ORCID: https://orcid.org/0000-0002-8217-8288

Universidade Federal do Amazonas, Brasil E-mail: paulaviana_lima@hotmail.com

Lucas de Jesus Pereira

ORCID: https://orcid.org/0000-0002-3938-3286

Universidade de São Paulo, Brasil

E-mail: lucas-laje@hotmail.com

Natalie Kesle Costa Tavares

ORCID: https://orcid.org/0000-0002-0482-6999

Universidade Federal do Amazonas, Brasil

E-mail: natalietavares.nt@gmail.com

Rodrigo Damasceno Costa

ORCID: https://orcid.org/0000-0002-1442-001X Distrito Sanitário Especial Indígena Médio Rio Purus, Brasil

E-mail: rodrigo-damasceno@outlook.com

Tainan Fabrício da Silva

ORCID: https://orcid.org/0000-0001-6761-1365

Universidade Federal do Amazonas, Brasil E-mail: tainanfabricio@ hotmail.com

Bárbara Leticia Corrêa Gomes ORCID: https://orcid.org/0000-0002-9875-8981 Universidade Federal do Pará, Brasil E-mail: barbaraltc4gomes@gmail.com

João Victor Corrêa Pinto

ORCID: https://orcid.org/0000-0003-2513-4657 Universidade Federal do Pará, Brasil E-mail: jvcorreapinto@gmail.com

Charles Carvalho dos Santos

ORCID: https://orcid.org/0000-0002-8572-0482

Universidade da Amazônia, Brasil

E-mail: charlestcheik@hotmail.com

Thalissa de Oliveira Vasconcelos

ORCID: https://orcid.org/0000-0002-3189-564X Faculdade Paraense de Ensino, Brasil E-mail: thalissa.julia@yahoo.com.br

Karina Teixeira Dutra

ORCID: https://orcid.org/0000-0002-4828-8256 Faculdade Paraense de Ensino, Brasil Email: Karinadutra26@gmail.com 


\author{
Janaina de Freitas Vale \\ ORCID: https://orcid.org/0000-0001-6063-672X \\ Universidade da Amazônia, Brasil \\ E-mail: janainadefreitasvale@yahoo.com.br \\ Francinéa de Nazaré Ferreira de Castilho \\ ORCID: https://orcid.org/0000-0002-9278-0010 \\ Universidade do Estado do Pará, Brasil \\ E-mail: francineacastilho@ hotmail.com \\ Djenanne Simonsen Augusto de Carvalho Caetano \\ ORCID: https://orcid.org./0000-0001-7987-3178 \\ Universidade do Estado do do Pará, Brasil \\ E-mail: djenanne.caetano@uepa.br \\ Dayara de Nazaré Rosa de Carvalho \\ ORCID: https://orcid.org/0000-0001-8569-3392 \\ Universidade do Estado do Pará, Brasil \\ E-mail: dayara_twain@hotmail.com \\ Maicon de Araújo Nogueira \\ ORCID: https://orcid.org/0000-0002-8315-4675 \\ Universidade do Estado do Pará, Brasil \\ E-mail: profmaiconnogueira@gmail.com \\ Antônia Margareth Moita Sá \\ ORCID: https://orcid.org/0000-0002-2053-5622 \\ Universidade do Estado do Pará, Brasil \\ E-mail: margarethsa@gmail.com
}

\begin{abstract}
Resumo
Objetivo: Analisar as evidências científicas disponíveis na literatura sobre uso do Desfibrilador Externo Automático (DEA) por pessoas leigas no atendimento Pré-hospitalar. Metodologia: trata-se de uma revisão integrativa da literatura. A busca realizada identificou 207 artigos, 162 na PUBMED, 28 no LILACS e 17 na BDENF. A seleção dos artigos para a elaboração do estudo iniciou pela exclusão de 27 artigos duplicados nas bases de dados; realizou-se análise dos títulos, resumos e os descritores de 180 artigos. Assim, foram selecionados inicialmente 29 artigos para leitura integral a partir dos critérios de inclusão, considerando o recorte temporal de 2015 a 2020, onde foram excluídos 17 artigos, dos quais foram elencados 12 textos completos para leitura e síntese. Resultados: Ficou evidenciado que os casos de paradas cardíacas fora do hospital ocorrem com frequência no mundo, levando a morte frequente dos pacientes, também se evidenciou que a desfibrilação precoce pode salvar tais vidas. As pesquisas remetem a uma série de lacunas em relação ao conhecimento das medidas e procedimentos técnicos de Suporte Básico de Vida (SBV) por pessoas leigas, assim como, a utilização do DEA em vítimas de paradas cardíacas fora do ambiente hospitalar. Conclusão: A pesquisa sintetiza as evidências científicas disponíveis na literatura sobre uso DEA por pessoas leigas no atendimento Pré-hospitalar; os dados apontam para um cenário de que a identificação das paradas cardiorrespiratórias fora do ambiente hospitalar e o início precoce de manobras contidas nas práticas de SBV nas vítimas em PCR é fundamental para aumentar a sobrevida.
\end{abstract}

Palavras-chave: Desfibrilador externo automatizado; Ressuscitação cardiopulmonar; Suporte básico de vida; Parada cardiorrespiratória.

\begin{abstract}
Objective: To analyze the scientific evidence available in the literature on the use of the Automatic External Defibrillator (AED) by lay people in pre-hospital care. Methodology: this is an integrative literature review. The search carried out identified 207 articles, 162 at PUBMED, 28 at LILACS and 17 at BDENF. The selection of articles for the preparation of the study began by excluding 27 duplicate articles in the databases; analysis of the titles, abstracts and descriptors of 180 articles was carried out. Thus, 29 articles were initially selected for full reading based on the inclusion criteria, considering the time frame from 2015 to 2020, where 17 articles were excluded, from which 12 full texts were listed for reading and synthesis. Results: It was evidenced that cases of cardiac arrests outside the hospital occur frequently in the world, leading to the frequent death of patients, it was also shown that early defibrillation can save such lives. The researches refer to a series of gaps in relation to the knowledge of technical measures and procedures of Basic Life Support (BLS) by lay people, as well as the use of AED in victims of cardiac arrests outside the hospital environment. Conclusion: The research synthesizes the scientific evidence available in the literature on DEA use by lay people in Prehospital care; the data point to a scenario that the identification of cardiorespiratory arrest outside the hospital environment and the early onset of maneuvers contained in BLS practices in victims of CPA is essential to increase survival.
\end{abstract}

Keywords: Automated external defibrillator; Cardiopulmonary resuscitation; Basic suport of life; Cardiorespiratory Arrest. 


\section{Resumen}

Objetivo: Analizar la evidencia científica disponible en la literatura sobre el uso del Desfibrilador Externo Automático (DEA) por legos en la atención prehospitalaria. Metodologia: se trata de una revisión integradora de la literatura. La búsqueda realizada identificó 207 artículos, 162 en PUBMED, 28 en LILACS y 17 en BDENF. La selección de artículos para la elaboración del estudio se inició con la exclusión de 27 artículos duplicados en las bases de datos; Se realizó un análisis de los títulos, resúmenes y descriptores de 180 artículos. Así, inicialmente se seleccionaron 29 artículos para lectura completa a partir de los criterios de inclusión, considerando el marco temporal de 2015 a 2020 , donde se excluyeron 17 artículos, de los cuales se enumeraron 12 textos completos para lectura y síntesis. Resultados: Se evidenció que los casos de paros cardíacos fuera del hospital ocurren con frecuencia en el mundo, provocando la muerte frecuente de los pacientes, también se demostró que la desfibrilación temprana puede salvar tales vidas. Las investigaciones hacen referencia a una serie de lagunas en relación al conocimiento de las medidas y procedimientos técnicos de Soporte Vital Básico (SVB) por parte de los profanos, así como al uso de DEA en víctimas de paro cardíaco fuera del ámbito hospitalario. Conclusión: La investigación sintetiza la evidencia científica disponible en la literatura sobre el uso de DEA por personas no profesionales en la atención prehospitalaria; los datos apuntan a un escenario en el que la identificación de parada cardiorrespiratoria fuera del ámbito hospitalario y el inicio temprano de las maniobras contenidas en las prácticas de BLS de las víctimas en parada cardiaca es fundamental para incrementar la supervivencia.

Palabras clave: Desfibrilador externo automatizado; Reanimación cardiopulmonary; Apoyo básico de la vida; Paro cardiorespiratorio.

\section{Introdução}

As doenças cardiovasculares referem-se a um grupo de morbidades que envolvem coração e vasos sanguíneos, ou ainda, sequelas advindas de um suprimento sanguíneo vascular inadequado e atualmente estas doenças ocupam quarta posição nas causas de internação hospitalar, sendo a primeira causa de mortalidade no Brasil, onde, o ano de 2018 foram registradas 6.217.525 internações em adultos com idade entre 20 e 59 anos, e destas, 441.725 corresponderam às DCV (Figueiredo et al., 2020).

Nesse sentido, há alguns estudos indicando que as paradas cardíacas fora do ambiente hospitalar de natureza inesperada se mostram como um problema de saúde pública de grande magnitude (Weisfeldt; Pollack, 2017, Delgado et al., 2018, Pollack et al., 2018).

Nessa perspectiva, outras pesquisas mostram que medidas e procedimentos técnicos denominadas de Suporte Básico de Vida (SBV) propiciam o suporte de vida à vítima, ou seja, é possível afirmar que SBV se mostra de importância vital para que o Suporte Intermediário de Vida (SIV) chegue e transporte a vítima ao hospital (Silva et al., 2019, Merchant et al., 2020).

Quanto a Ressuscitação Cardiopulmonar (RCP), a literatura mostra que é uma manobra contidas nas práticas de SBV nas vítimas em Parada Cardiorrespiratória (PCR), assim como desfibrilação por meio dos Desfibriladores Externos Automáticos (DEA) e as manobras de desobstrução de vias aéreas devido a corpo estranho (Freitas; Péllenz, 2018, Oliveira et al., 2018).

Dessa maneira, verifica-se que é necessário que se reconheça o cenário de uma PCR e a necessidade de manobras relacionadas com a RCC e a possibilidade do atendimento básico imediato do paciente por leigos, desde que devidamente treinados e capacitados (Weisfeldt; Pollack, 2017, Delgado et al., 2018).

Assim, é possível verificar um ponto em comum nas pesquisas de Weisfeldt; Pollack (2017), Silva et al., (2019) e Merchant et al. (2020) o fato de que a utilização dos DEAs durante a parada cardíaca fora do hospital está associado à sobrevida, assim como, o objetivo principal é não agravar lesões já existentes ou gerar novas lesões (iatrogenias). Um rápido SBV proporciona até $60 \%$ de chance de sobrevivência

Sobre a desfibrilação, as pesquisas de Resende et al. (2019), Silva et al. (2019 e Silva et al. (2020), mostram que é a aplicação de corrente elétrica contínua, na região torácica, por meio do coração, em seu maior eixo, cuja finalidade é promover a despolarização simultânea do maior número possível de células cardíacas, através de um desfibrilador, um equipamento eletrônico cuja função é reverter um quadro de fibrilação auricular ou ventricular. 
Maia et al. (2020), destaca que a desfibrilação era um procedimento reservado à profissionais de saúde treinados em Suporte Avançado de Vida (SAV), muito embora, algumas pesquisa indicam que as versões recentes do DEA são representados por equipamentos de simples manuseio, podendo leigos ou profissionais manusearem sem nenhuma dificuldades desde que possuam treinamento no SBV, em que são etapas que podem ser iniciadas fora do ambiente hospitalar, realizadas por leigos devidamente treinados e capacitados, com a finalidade de aumentar a sobrevida da vítima e diminuir sequelas importantes (Santos et al., 2018, Carvalho et al., 2020, Landa; Ferreira, 2020).

Dessa maneira, autores como Ferreira et al. (2014), Neto et al. (2016) e Pollack et al. (2018), mostram que o DEA é um equipamento portátil, que possui um sistema computadorizado. Esse sistema analisa o ritmo cardíaco várias vezes em poucos segundos, através de eletrodos fixados ao paciente, detectando a necessidade da desfibrilação, que é um choque elétrico controlado a partir da presença de uma arritmia cardíaca geradora da PCR (FV e TV sem pulso), que é tida como ritmo cardíaco desfibrilável, ou seja, essa identificação permite o aparelho carregar e recomendar a aplicação do choque por meio de uma mensagem.

A justificativa da realização da presente pesquisa se dá por conta da necessidade de discutir a importância e impacto da utilização do DEA no SBV que propiciam o suporte de vida à vítima, no cenário brasileiro e mundial, assim como, levantar como vem sendo desenvolvida a construção do conhecimento relacionada com o uso de DEA antes da chegada dos serviços médicos de emergência em locais fora do ambiente hospitalar e as possíveis contribuições para os melhores resultados de sobrevivência e funcionais do paciente com a PCR. Mostra-se também relevante a pesquisa pelo fato de que o índice de óbito em ambiente extra-hospitalar chegam a 80\% quando não há um reconhecimento dos sinais, sintomas e da gravidade em que se encontra, mostrando-se de grande importância o uso por leigos dos DEA no SBV que propiciam o suporte de vida à vítimas (Pivati et al., 2019).

Em um estudo realizado em Rochester, Minnesota, através de uma longa observação e testes realizados em atendimentos por policiais que foram treinados para o uso do DEA, ocorreu uma melhora de desempenho e sobrevivência. Esse fato também foi observado em estudos realizados com o uso do DEA em aeronaves comerciais em Seattle e em aeroportos em Chicago (Carvalho et al., 2020).

Já em ambiente extra-hospitalar com grande fluxo de pessoas, realizado em Vancouver, no período da pesquisa ocorreram 05 casos de PCR e em 2 o ritmo era desfibrilável e obteve-se sucesso, estando os pacientes recobrando a consciência quando o serviço de emergência chegou ao local. Já na Escócia, foi considerado que a utilização do DEA em locais públicos, adequados, aumentaria a sobrevivência de 744 casos (5\%) a 942 casos (6,3\%) (Ferreira et al., 2014).

Nessa perspectiva, o objetivo desta pesquisa foi analisar as evidências científicas disponíveis na literatura sobre uso do Desfibrilador Externo Automático (DEA) por pessoas leigas no atendimento Pré-hospitalar.

\section{Metodologia}

Para a realização deste estudo, utilizou-se o método de revisão integrativa da literatura, definida como um método de revisão específico que visa fornecer uma visão abrangente sobre determinado tema e que tenha utilidade para a prática. Dessa forma, segundo Yonekura et al. (2019), a revisão integrativa, busca revisar, criticar e sintetizar os resultados utilizando métodos interpretativos e críticos, esta revisão orientará a análise de acordo com o paradigma crítico. Nogueira et al. (2020) também elencam as seguintes etapas para a realização da Revisão Integrativa da Literatura: estabelecimento da questão de pesquisa, revisão da literatura, categorização de estudos, avaliação de estudos e interpretação dos resultados e síntese do conhecimento como mostra a Figura 1. 
Figura 1 - Etapas da Revisão Integrativa da Literatura segundo Nogueira et al. (2020).

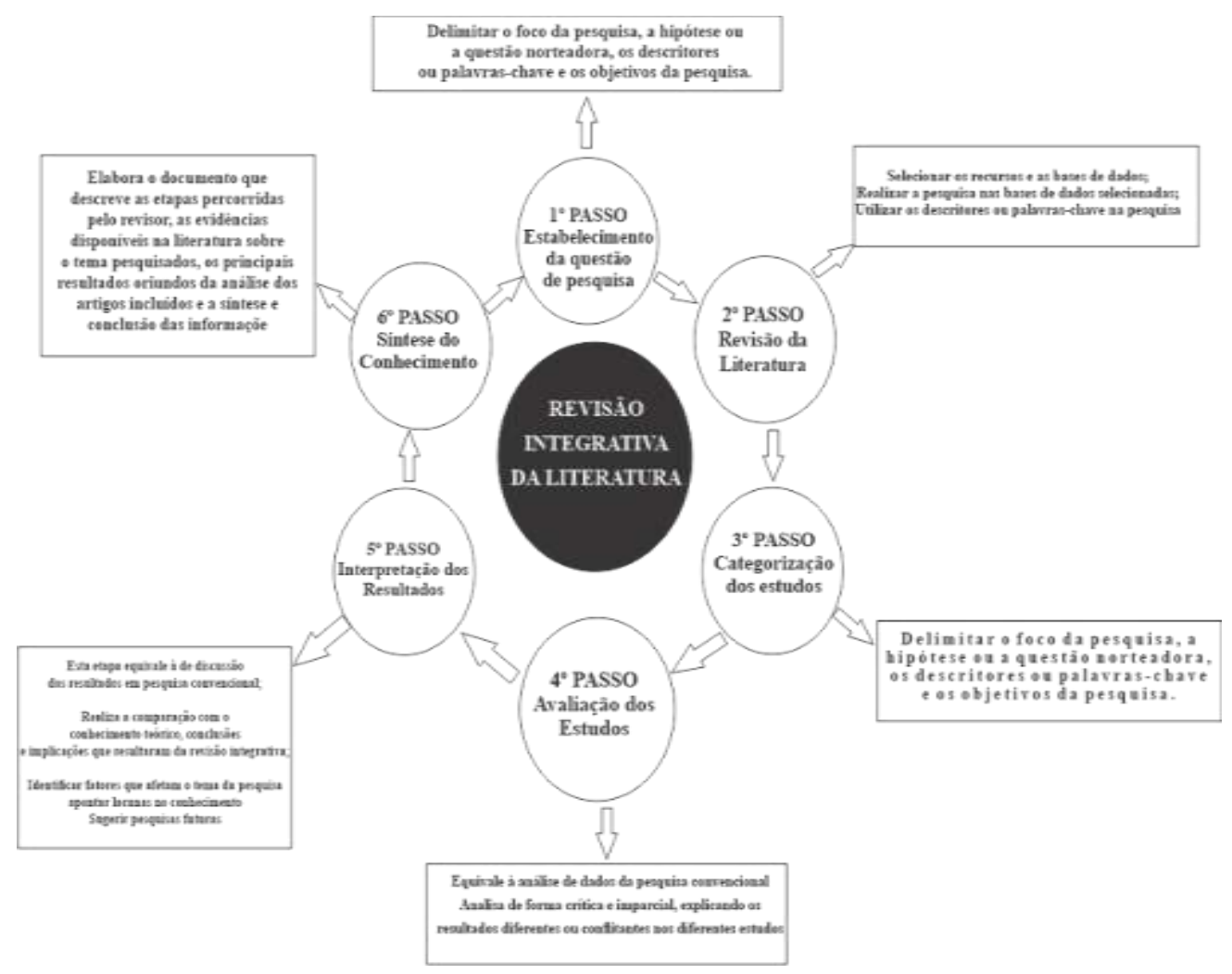

Fonte: Elaborado por autores, adaptado de Nogueira et al. (2020).

A questão da pesquisa foi construída por meio da estratégia PICO (acrônimo para patient, intervention, comparison, outcomes) desenvolvida com o intuito de orientar a construção da pergunta norteadora de pesquisa e na condução da identificação de palavras-chave, assim como, permite que se localize pesquisa primárias e relevantes nas bases de dados de modo acurado e rápido, a melhor informação científica disponível (Quadro 1) Santos et al. (2007 como citado em Nogueira et al., 2020, p. 121).

Quadro 1 - Construção da pergunta norteadora através da estratégia PICO.

\begin{tabular}{|l|l|l|}
\hline $\mathbf{P}$ & (Paciente ou problema) & Pessoas leigas da comunidade em geral \\
\hline $\mathbf{I}$ & (Intervenção) & Formação para o uso de DEA em ambiente extra-hospitalar \\
\hline $\mathbf{C}$ & (Controle ou comparação) & $\begin{array}{l}\text { Identificação dos artigos que contenham informações acerca da atuação dos leigos } \\
\text { no uso do DEA em PCR no ambiente pré-hospitalar seguindo as recomendações } \\
\text { dos Guidelines e demais protocolos. }\end{array}$ \\
\hline $\mathbf{O}$ & (Desfecho ou "Outcomes") & $\begin{array}{l}\text { Obtenção de estudos que abordem a importância de leigos treinados para o uso do } \\
\text { DEA em SBV em ambiente pré-hospitalar de acordo com as atuais } \\
\text { recomendações. }\end{array}$ \\
\hline
\end{tabular}

Fonte: Adaptado de Santos; Pimenta; Nobre, 2007 apud Nogueira et al., 2020, p. 121.

Após a utilização da estratégia PICO, a pergunta norteadora da pesquisa foi a seguinte: Quais as evidências científicas disponíveis na literatura sobre o uso do DEA em SBV em ambiente pré-hospitalar por pessoas leigas?

A busca foi realizada nas bases de dados PUBMED, LILACS e BDENF nos meses de março a junho de 2020. 
Ao realizar a pesquisa no PUBMED, buscou-se trabalhar com os descritores controlados pelo MESH, utilizando a estratégia "Construtor de pesquisa PubMed"/ "PubMed Search Builder". Ao localizar o termo no MESH, estes foram mobilizados para a caixa referida; depois de selecionados todos os termos do mesmo nível e operador booleano, clicou-se no botão "Adicionar Construtor de Pesquisa"/ "Add Search Builder". Feito isto, clicou-se no botão "Pesquisar PubMed”/ "Search PubMed", obtendo-se os estudos a partir da estratégia estabelecida e elegidos da seguinte maneira em português/inglês:

Quadro 2 - Termos no MESH utilizados na pesquisa no banco de dados da PUBMED.

\begin{tabular}{|l|l|}
\hline Defibrillator & Desfibrilador \\
\hline Electric Shock Cardiac Stimulators & Estimuladores cardíacos de choque elétrico \\
\hline Stimulators, Electrical, Cardiac, Shock & Estimuladores elétricos, cardíacos, de choque \\
\hline Automated External Defibrillator & Desfibrilador Externo Automatizado \\
\hline Defibrillator Automated External & Desfibrilador Externo Automático \\
\hline External Defibrillator, Automated & Desfibrilador externo, automatizado \\
\hline External Defibrillator & Desfibrilador Externo \\
\hline
\end{tabular}

Fonte: Elaborado pelos autores (2021).

Os critérios de inclusão foram: artigos em português e inglês, publicados entre 2015 a 2020, que abordassem o uso de DEA por pessoas leigas e artigos completos na versão livre. Os critérios de exclusão foram: artigos que não abordavam o uso de DEA por pessoas leigas, artigos que o foco era estudante ou profissionais da saúde e artigos onde somente os resumos estavam disponíveis, teses, dissertações, monografias, trabalhos de conclusão de curso, anais de eventos, cartas editoriais.

A busca das publicações foi feita em junho de 2019, nas seguintes bases de dados: PUBMED, LILACS e BDENF. Para a busca foram utilizados os seguintes descritores e operadores Booleanos: PubMed: automated external defibrillators OR Laypersons OR Cardiopulmonary resuscitation AND Public access resuscitation; LILACS e BDENF: bystander cardiopulmonary resuscitation AND heart arrest OR cardiopulmonary resuscitation.

Dessa maneira, identificou-se cerca de 207 artigos nas bases de dados, sendo que 162 na PUBMED, 28 no LILACS e 17 na BDENF. A seleção dos artigos para a elaboração do estudo iniciou-se pela remoção de 27 artigos duplicados presentes em mais de uma base de dados; após esta etapa realizou-se uma leitura e análise dos títulos, resumos e os descritores de 180 artigos, na qual, 29 artigos enquadraram-se nos requisitos da revisão integrativa. Em uma nova filtragem a leitura dos 29 ficaram elegíveis para leitura íntegra, analisando individualmente cada artigo e aplicando critérios de inclusão e exclusão.

Para sistematização dos artigos selecionados na busca, foi definida a partir dos ensinamentos de Welchet et al. (2016) que orienta a utilização do fluxograma Prisma Statemen, ou seja, realizou-se de forma criteriosa a leitura dos títulos e resumos dos artigos, posteriormente à primeira análise, foi desenvolvida a leitura na íntegra, com o objetivo de identificar os textos que atendiam a pergunta de estudo e os critérios de inclusão/exclusão. Os artigos foram excluídos incialmente por serem duplicados, em seguida por não atenderem a questão do estudo, sejam na leitura inicial ou na íntegra (Figura 2). 
Figura 2 - Fluxograma de PRISMA, processo de identificação, análise e seleção dos estudos.

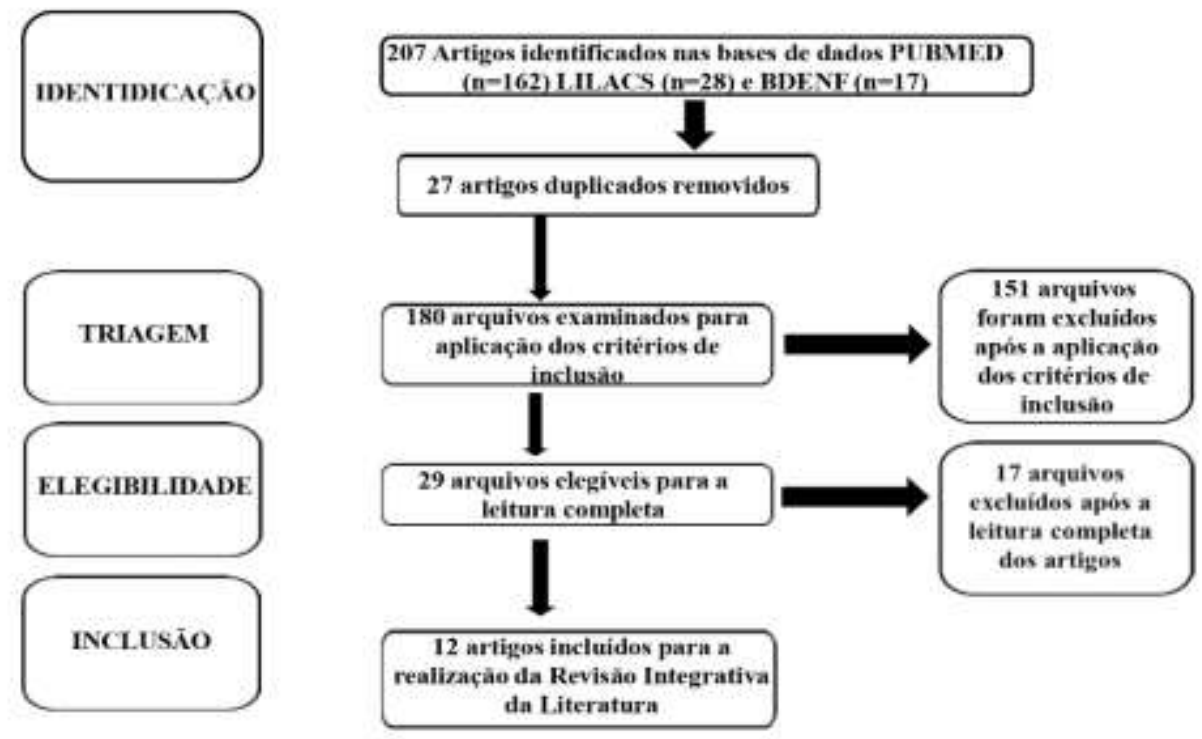

Fonte: Elaborado pelos autores, Fluxo de Prisma (2021).

\section{Resultados}

Após realizar a análise das informações contidas nos artigos selecionados dois revisores de forma individual. Deste modo, uma planilha foi criada no Microsoft Word $^{\circledR}$ para a extração das informações mais pertinentes de cada estudo, as variáveis determinadas foram: Autores; título, base de dados e ano, objetivo e achados da pesquisa. Após realizada a tabulação uma nova avaliação por parte dos autores da pesquisa foi feita, de forma que, alcançassem um consenso para cada dado extraído e que as informações obtidas fossem sintetizadas e integralizadas, transcrevendo as dúvidas desta pesquisa (Soares et al., 2014, p. 48).

Após o refinamento realizado por uma última filtragem com os termos "Desfibrilador Externo Automatizado (Automated External Defibrillators) e leigo (layperson)", ficaram elegíveis 12 artigos, conforme o Gráfico 1.

Gráfico 1 - Artigos utilizados na Revisão da literatura por ano da publicação.

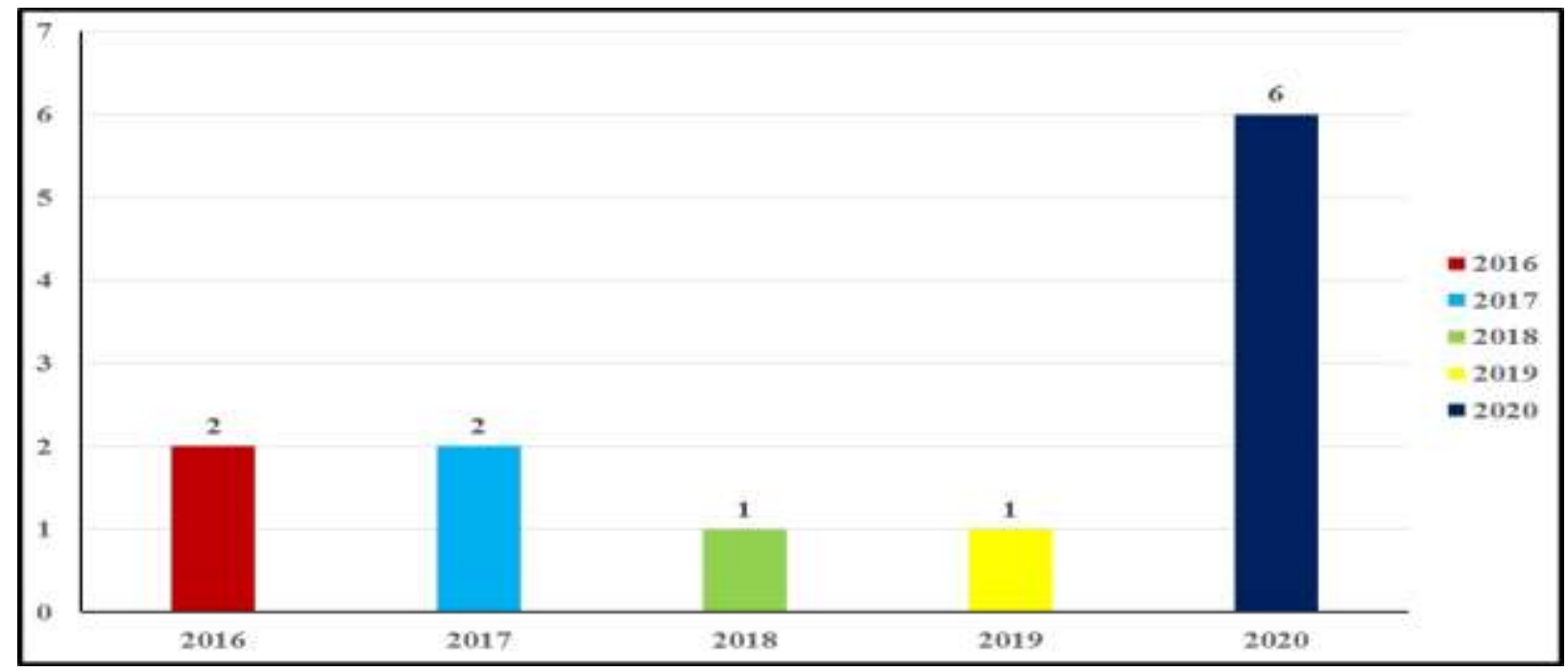

Fonte: Elaborado pelos autores (2021). 
Quanto a base de dados, verificou-se que 58,3\% dos artigos eleitos são da PUBMED, 25,0\% da LILACS e 16,7\% da BDENF, como pode ser visto no Gráfico 2.

Gráfico 2 - Percentual dos artigos utilizados na Revisão da literatura por banco de dados.

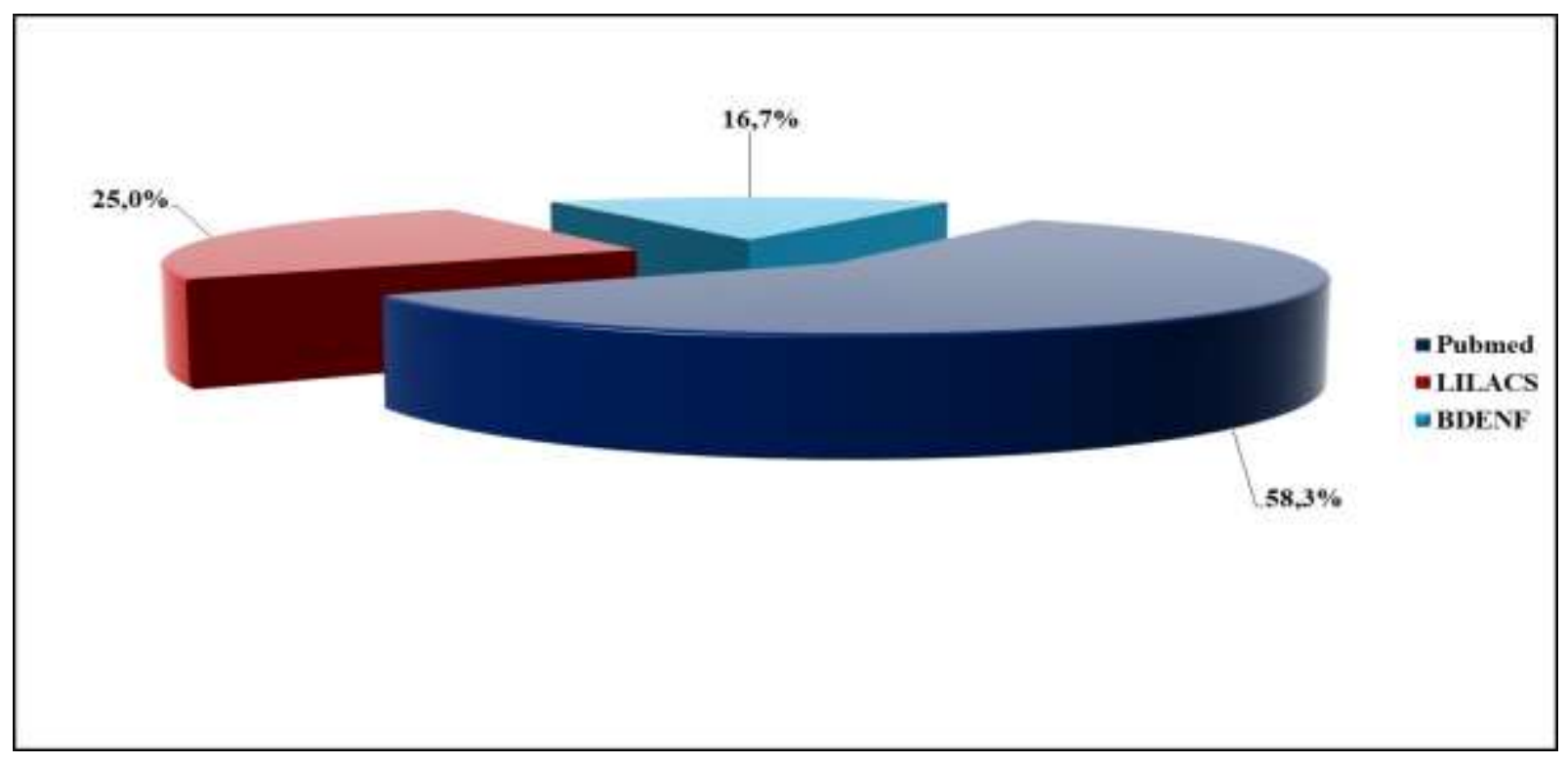

Fonte: Elaborado pelos autores (2021).

Em relação ao idioma dos artigos, 58,3\% são em inglês e 41,7\% em português, como fica demonstrado no Gráfico 3 .

Gráfico 3 - Percentual dos artigos utilizados na Revisão da literatura pelo idioma.

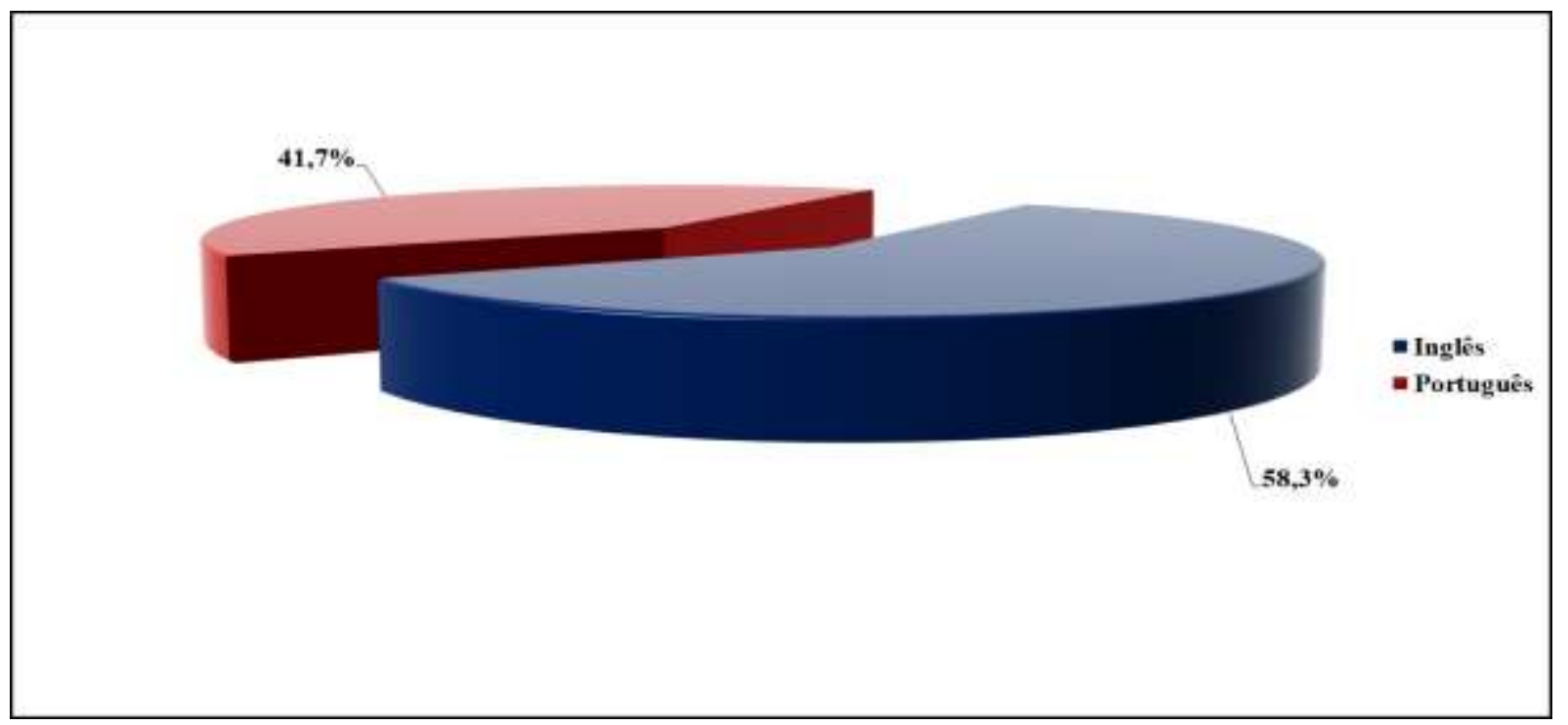

Fonte: Elaborado pelos autores (2021).

O Quadro 3 apresenta, de forma sintética, mostra-se as informações extraídas dos artigos eleitos da seguinte maneira: Autores; título, base de dados e ano, objetivo e achados da pesquisa. 
Quadro 3 - Síntese dos artigos segundo autor, título, periódico, ano, procedimento metodológico e achados da pesquisa.

\begin{tabular}{|c|c|c|c|}
\hline Autor. Título. Periódico. Ano & $\begin{array}{c}\text { Base de } \\
\text { dados }\end{array}$ & $\begin{array}{l}\text { Procedimento } \\
\text { metodológico }\end{array}$ & Achados da pesquisa \\
\hline $\begin{array}{l}\text { CHEHUEN NETO, José Antônio et al. } \\
\text { Conhecimento e interesse sobre suporte } \\
\text { básico de vida entre leigos. Int J Cardiovasc } \\
\text { Sci, v. 29, n. 6, p. 443-452, } 2016 \text {. }\end{array}$ & LILACS & $\begin{array}{l}\text { Pesquisa } \\
\text { transversal, } \\
\text { exploratória e } \\
\text { descritiva }\end{array}$ & $\begin{array}{l}\text { Pesquisa realizada com } 410 \text { funcionários de } \\
\text { centros comerciais com afluxo diário mínimo } \\
\text { estimado de cem pessoas no município de Juiz de } \\
\text { Fora. Observou-se que } 34,9 \% \text { dos homens e } 22,2 \% \\
\text { das mulheres sabiam reconhecer uma PCR (RP = } \\
87,0 \% ; p=0,007) ; 84,2 \% \text { dos homens e } 72,0 \% \\
\text { das mulheres sabiam em qual situação usar o DEA } \\
(\mathrm{RP}=107 \% \text {; } \mathrm{p}=0,006 \text { ); e } 53,3 \% \text { dos homens e } \\
37,8 \% \text { das mulheres conheciam o momento de } \\
\text { interromper a massagem cardíaca (RP = 88,0\%; } \mathrm{p} \\
=0,003 \text { ). }\end{array}$ \\
\hline $\begin{array}{l}\text { YOON, Chang Guk et al. Availability and } \\
\text { use of public access defibrillators in Busan } \\
\text { Metropolitan City, South Korea. } \\
\text { Springerplus, v. 5, n. 1, p. 1-5, } 2016 \text {. }\end{array}$ & $\begin{array}{l}\text { PUBME } \\
\text { D }\end{array}$ & $\begin{array}{l}\text { Pesquisa } \\
\text { exploratória, } \\
\text { descritiva }\end{array}$ & $\begin{array}{l}\text { Pesquisa buscou localizar locais potenciais de } \\
\text { AED que incluíam aeroportos, estações } \\
\text { ferroviárias, terminais de balsas e ônibus, cassinos, } \\
\text { instalações de correção, escritórios } \\
\text { governamentais, instalações esportivas, entre } \\
\text { outros. No total, foram localizados } 206 \text { AEDs, } \\
\text { indicando uma densidade de AED de } 0,268 \text { AED / } \\
\text { km2 e uma prevalência de } 6,07 \text { por } 100.000 \\
\text { habitantes na cidade metropolitana de Busan. }\end{array}$ \\
\hline $\begin{array}{l}\text { STEIN, Philipp et al. Impact of city police } \\
\text { layperson education and equipment with } \\
\text { automatic external defibrillators on patient } \\
\text { outcome after out of hospital cardiac arrest. } \\
\text { Resuscitation, v. } 118 \text {, p. } 27-34,2017 \text {. }\end{array}$ & $\begin{array}{l}\text { PUBME } \\
\text { D }\end{array}$ & $\begin{array}{l}\text { Estudo } \\
\text { Retrospectivo } \\
\text { observacional }\end{array}$ & $\begin{array}{l}\text { Pesquisa realizada com policias da cidade de } \\
\text { Zurique que atuam no serviço de SBV. Os sujeitos } \\
\text { da pesquisa foram divididos na turma que treinou } \\
\text { entre 2004-2009 e a turma que treinou no 2010- } \\
\text { 2015. Foi possível constatar que o envio de forças } \\
\text { policiais treinadas em SBV e equipadas com AED } \\
\text { resulta na ressuscitação mais precoce e bem- } \\
\text { sucedida das vítimas de parada cardíaca fora do } \\
\text { hospital, levando a proporções mais elevadas de } \\
\text { pacientes com pacientes com retorno da circulação } \\
\text { espontânea, internação hospitalar e sobrevivência } \\
\text { até a alta hospitalar. }\end{array}$ \\
\hline $\begin{array}{l}\text { MALTA HANSEN, Carolina et al. Lay } \\
\text { bystanders' perspectives on what facilitates } \\
\text { cardiopulmonary resuscitation and use of } \\
\text { automated external defibrillators in real } \\
\text { cardiac arrests. Journal of the American Heart } \\
\text { Association, v. } 6, \text { n. } 3 \text {, p. e004572, } 2017 \text {. }\end{array}$ & $\begin{array}{l}\text { PUBME } \\
\text { D }\end{array}$ & $\begin{array}{l}\text { Pesquisa } \\
\text { transversal, } \\
\text { exploratória } \\
\text { descritiva }\end{array}$ & $\begin{array}{l}\text { Cento e vinte e oito entrevistas qualitativas } \\
\text { semiestruturadas com espectadores leigos } \\
\text { treinados em RCP em parada cardíaca consecutiva } \\
\text { fora do hospital, onde um DEA estava presente, } \\
\text { foram realizadas (de janeiro de } 2012 \text { a abril de } \\
2015 \text {, na Dinamarca). Vinte e seis das } 128 \\
\text { entrevistas foram escolhidas para análises mais } \\
\text { aprofundadas, até a saturação dos dados. Usamos } \\
\text { indexação transversal (usando software) e análises } \\
\text { temáticas indutivas em profundidade para }\end{array}$ \\
\hline
\end{tabular}




\begin{tabular}{|c|c|c|c|}
\hline & & & $\begin{array}{l}\text { identificar os fatores que facilitaram o uso de } \\
\text { Desfibrilador externo automático. Demonstrou-se } \\
\text { que Vários fatores, além do treinamento prático } \\
\text { anterior em RCP, facilitam a instigação do } \\
\text { observador leigo sobre o uso de RCP e DEA. O } \\
\text { reconhecimento e a modificação desses fatores } \\
\text { podem aumentar as taxas de RCP de espectadores } \\
\text { leigos e a sobrevida do paciente após uma parada } \\
\text { cardíaca fora do hospital. }\end{array}$ \\
\hline $\begin{array}{l}\text { WANG, Tsung-Hsi et al. The utilization of } \\
\text { automated external defibrillators in Taiwan. } \\
\text { Journal of the Formosan Medical } \\
\text { Association, v. 118, n. 1, p. 148-151, } 2018 \text {. }\end{array}$ & $\begin{array}{l}\text { PUBME } \\
\text { D }\end{array}$ & $\begin{array}{l}\text { Pesquisa } \\
\text { exploratória, } \\
\text { descritiva }\end{array}$ & $\begin{array}{l}\text { A pesquisa analisou } 217 \text { casos nos quais AEDs foi } \\
\text { usado entre } 11 \text { de julho de } 2013 \text { e } 31 \text { de julho de } \\
\text { 2015. A estatística descritiva foi usada para } \\
\text { analisar os dados. A maior frequência de uso de } \\
\text { AEDs foi em instituições de longa permanência, } \\
\text { correspondendo a } 34(15,7 \%) \text { casos. Portanto, } \\
\text { pode-se dizer que As instalações de cuidados de } \\
\text { longa duração tiveram a maior utilização de AEDs } \\
\text { e o governo deve prestar mais atenção para fazer } \\
\text { cumprir a instalação de AEDs nesses locais. O } \\
\text { governo também precisa promover a educação do } \\
\text { público sobre como pesquisar os locais de AEDs. }\end{array}$ \\
\hline $\begin{array}{l}\text { HALIQ, S. A. A. et al. Automated External } \\
\text { Defibrillator Issues and Challenges in Saudi } \\
\text { Arabia: Knowledge Assessment among } \\
\text { Laypersons; Public Safety Perspective. } 2019 .\end{array}$ & LILACS & $\begin{array}{l}\text { Estudo com } \\
\text { desenho descritivo }\end{array}$ & $\begin{array}{l}\text { A pesquisa foi desenvolvida em sete shoppings } \\
\text { localizados na Zona Leste da província da Arábia } \\
\text { Saudita. Duzentos e cinquenta participantes foram } \\
\text { entrevistados usando American Heart Diretrizes } \\
d a \text { Association (AHA) } 2015 \text { para avaliar o } \\
\text { conhecimento em ressuscitação cardiopulmonar e } \\
\text { Desfibrilador externo automático. Os resultados do } \\
\text { estudo indicaram um treinamento insuficiente de } \\
\text { ressuscitação cardiopulmonar e Desfibrilador } \\
\text { externo automático em ambientes públicos. }\end{array}$ \\
\hline $\begin{array}{l}\text { KOBAYASHI, Daisuke et al. Public location } \\
\text { and survival from out-of-hospital cardiac } \\
\text { arrest in the public-access defibrillation era in } \\
\text { Japan. Journal of cardiology, v. } 75 \text {, n. } 1 \text {, p. } \\
\text { 97-104, } 2020 \text {. }\end{array}$ & $\begin{array}{l}\text { PUBME } \\
\text { D }\end{array}$ & $\begin{array}{l}\text { Estudo prospectivo } \\
\text { e populacional }\end{array}$ & $\begin{array}{l}\text { A pesquisa foi realizada a partir de um registro } \\
\text { nacional, prospectivo e populacional de pacientes } \\
\text { após parada cardíaca fora do hospital no Japão, } \\
\text { inscrevemos pacientes adultos com parada } \\
\text { cardíaca fora do hospital testemunhados por } \\
\text { espectadores de origem médica em locais públicos } \\
\text { entre } 2013 \text { e } 2015 \text {. Os achados demonstraram que } \\
\text { no Japão, onde AEDs de acesso público são bem } \\
\text { disseminados, o programa PAD funcionou } \\
\text { eficazmente para OHCA adulto de origem médica } \\
\text { que ocorre em locais públicos. Notavelmente, as } \\
\text { proporções de PAD diferiram substancialmente de } \\
\text { acordo com locais públicos específicos. }\end{array}$ \\
\hline
\end{tabular}




\begin{tabular}{|c|c|c|c|}
\hline $\begin{array}{l}\text { DONG, Xue-jie et al. The general public's } \\
\text { ability to operate automated external } \\
\text { defibrillator: A controlled simulation study. } \\
\text { World Journal of Emergency Medicine, v. } 11 \text {, } \\
\text { n. } 4 \text {, p. } 238,2020 \text {. }\end{array}$ & $\begin{array}{l}\text { PUBME } \\
\text { D }\end{array}$ & $\begin{array}{l}\text { Estudo prospectivo } \\
\text { de simulação }\end{array}$ & $\begin{array}{l}\text { A pesquisa foi conduzida com } 94 \text { leigos com } \\
\text { idades entre 18-65 anos ( } 32 \text { com 18-24 anos, } 34 \\
\text { com 25-54 anos e } 28 \text { com 55-65 anos) sem } \\
\text { treinamento prévio de AED. Mostrou-se que } \\
\text { maioria dos leigos não treinados não consegue } \\
\text { operar o DEA com eficácia. Treinamento mais } \\
\text { frequente e cursos de atualização são cruciais para } \\
\text { melhorar as habilidades de AED. }\end{array}$ \\
\hline $\begin{array}{l}\text { SOUZA, Reginaldo Pereira et al. Parada } \\
\text { cardiorrespiratória: avaliação teórica das } \\
\text { condutas EMERGENCIAIS DE PESSOAS } \\
\text { LEIGAS. Revista Renome, v. 9, n. 1, p. 29- } \\
\text { 39, } 2020 \text {. }\end{array}$ & LILACS & $\begin{array}{l}\text { Estudo quantitativo, } \\
\text { transversal, de } \\
\text { caráter descritivo. }\end{array}$ & $\begin{array}{l}\text { Foi desenvolvido uma pesquisa amostra } \\
\text { probabilística, com representatividade municipal, } \\
\text { de } 397 \text { transeuntes respondeu questionário } \\
\text { estruturado pré testado. Fivou evidenciado que os } \\
\text { participantes possuem conhecimentos limitados } \\
\text { sobre o SBV e uso do desfibrilador externo } \\
\text { automático (DEA), e diante de uma situação real, } \\
\text { poderiam comprometer o prognóstico das vítimas } \\
\text { de PCR. }\end{array}$ \\
\hline $\begin{array}{l}\text { CARVALHO, Lorena Rodrigues de et al. } \\
\text { Fatores associados ao conhecimento de } \\
\text { pessoas leigas sobre suporte básico de vida. } \\
\text { Enfermería Actual de Costa Rica, n. 38, p. } \\
\text { 163-178, } 2020 \text {. }\end{array}$ & $\bar{F}$ & $\begin{array}{l}\text { Estudo } \\
\text { epidemiológico, } \\
\text { descritivo, de corte } \\
\text { transversal, }\end{array}$ & $\begin{array}{l}\text { Estudo desenvolvido com } 65 \text { funcionários de um } \\
\text { Campus da Universidade do Estado da Bahia, por } \\
\text { meio de entrevistas. Através dos resultados obtidos } \\
\text { nesse estudo, foi possível observar que o leigo } \\
\text { possui conhecimento insuficiente sobre PCR e } \\
\text { RCP, sobretudo no que diz respeito à forma } \\
\text { correta de facilitar a respiração, quantidade de } \\
\text { compressões por minuto em situações de PCR e } \\
\text { funcionalidade do desfibrilador externo } \\
\text { automático. O desconhecimento pode levar a uma } \\
\text { assistência insatisfatória quando prestada. }\end{array}$ \\
\hline $\begin{array}{l}\text { MAIA, Samuel Ramalho Torres et al. } \\
\text { Conhecimento dos leigos acerca da } \\
\text { ressuscitação cardiopulmonar em pacientes } \\
\text { adultos no Brasil. Brazilian Journal of } \\
\text { Development, v. 6, n. 5, p. 28933-28948, } \\
2020 .\end{array}$ & BDENF & $\begin{array}{l}\text { Estudo exploratório, } \\
\text { do tipo pesquisa } \\
\text { bibliográfica }\end{array}$ & $\begin{array}{l}\text { Identificou-se como resultados que os leigos não } \\
\text { apresentam um conhecimento prévio, poucos } \\
\text { fizeram treinamentos/cursos, mas sabem da } \\
\text { importância em tê-los. Em todos os itens/quesitos } \\
\text { de avaliação do conhecimento, observou um } \\
\text { aumento significativo após capacitações teórico- } \\
\text { práticas }\end{array}$ \\
\hline
\end{tabular}

Fonte: Elaborado pelos autores (2021).

\section{Discussão}

\section{A importância do uso de desfibrilador externo automático e a sobrevida dos pacientes com parada cardiorrespiratória}

De uma maneira geral é possível perceber em várias pesquisas da literatura pesquisada que a primeira evidência encontrada nos estudos analisados apontam para a importância do uso da desfibrilação por meio do DEA nos atendimentos de SBV como forma de dar sobrevida e prevenir sequelas aos pacientes com parada cardiorrespiratória, especialmente, nos casos 
em que a equipe especializada ainda não esteja no local do acontecimento (Neto et al., 2016; Yoon et al., 2016; Wang et al., 2018, Kobayashi et al., 2020)

Sobre essa questão Neto et al. (2016) afirma que o atendimento inicial de situações de emergência é conhecido como SBV, e sua aplicação é fundamental para salvar vidas e prevenir sequelas, entre as manobras responsáveis pela sobrevida dos pacientes com parada cardiorrespiratória está a desfibrilação por meio dos DEAs. Ainda sobre este assunto, Yoon et al. (2016) acenam para a ideia de que a parada cardíaca fora do hospital pode ser é considerada um importante problema de saúde em todo o mundo e a taxa de sobrevivência desses pacientes é baixa, por isso, a desfibrilação precoce é um elemento-chave para um prognóstico favorável.

Outra pesquisa que se coaduna com o cenário anterior, é o estudo de Kobayashi et al. (2020) ressalta que a desfibrilação precoce por espectadores melhora a sobrevivência dos pacientes após paradas cardíacas fora dos hospitais. Os referidos autores citam também um estudo realizado no Japão que registrou a dimensão dos casos de paradas cardíacas fora dos hospitais, onde, constatou-se mais de 20.000 casos de testemunhados por espectadores de origem médica que ocorreram em locais públicos entre 2013 e 2015.

Diante deste contexto, fica evidente que os casos de paradas cardíacas fora do hospital ocorrem com frequência no mundo, e os resultados dessas ocorrências costumam ser desanimadores, inclusive chegando a levar morte dos pacientes, ficou evidenciado também que a desfibrilação precoce pode salvar vidas após paradas cardíacas fora dos hospitais.

Corroborando a evidência anterior, a pesquisa de Wang et al. (2018), mostrou que o aumento da atenção ao atendimento aos pacientes que sofreram a parada cardíaca fora do hospital pode ter a sobrevida quando utilizadas as manobras de SBV, principalmente, com a utilização dos DEAs, o estudo mostrou ainda que em Taiwan, há uma legislação específica chamada Lei de Serviços Médicos de Emergência determinando a instalação de DEAs em áreas designadas desde o ano de 2013.

Infere-se o entendimento de que a parada cardíaca fora do hospital é um grande problema de saúde mundial, ou seja, ficou evidente que esse problema se mostra como um grande desafio para o sistema médico de emergência, pois há uma significativa diminuição da taxa de mortalidade à partir do momento que as taxas de sobrevida diminuídas são diretamente proporcionais ao intervalo de tempo desde o colapso até a desfibrilação.

É importante ressaltar um ponto em comum nas pesquisas analisadas na presente revisão é a questão do fato de que a desfibrilação só era realizada por médicos e em hospitais, porém, com o desenvolvimento dos DEAs, a desfibrilação passou a ser possível ser realizada por profissionais não médicos e, subsequentemente, por pessoas leigas treinadas ou não treinadas.

Nessa perspectiva, é importante atentar sobre a importância de se ter pessoas capacitadas para manipular o DEA, ou seja, técnicos em atendimento médicos de emergência, bombeiros, muito embora, deve-se ter em mente que é de extrema importância o profissional ou a pessoa leiga saber reconhecer uma PCR, e iniciar medidas e procedimentos técnicos denominadas de SBV que podem propicia a sobrevida à vítima.

\section{Conhecimento e formação de leigos no uso do dea nos atendimentos de SBV}

Várias pesquisas mostraram um ponto em comum em suas abordagens é a questão de que mesmo sendo importante a utilização da desfibrilação pelos DEAs nos casos de PCR, porém, ficou evidente em várias pesquisas da literatura pesquisada que há o baixo uso de DEAs nos casos de paradas cardíacas fora do hospital, ou seja, as pesquisas remetem a ideia de que é necessário conhecimento e formação de leigos no uso do DEA nos atendimentos de SBV (Wang et al., 2018; Haliq et al., 2019; Kobayashi et al., 2020; Maia et al., 2020, Souza et al., 2020)

Um exemplo deste cenário é a afirmação de Kobayashi et al.(2020), ao apontarem que ainda existem várias lacunas de conhecimento e orientações em relação à utilização da desfibrilação de acesso público e a possibilidade de melhoramento dos 
resultados dos casos de paradas cardíacas fora do hospital. Além disso, os mesmos autores afirmam que o DEA pode ser considerado como uma inovação tecnológica que vem trazendo grandes contribuições para o aumento na sobrevivência de vítimas de PCR, principalmente, pela facilidade de operação, a confiabilidade e o fato de que praticamente qualquer pessoa que tenha um treinamento prévio, possa efetuar a desfibrilação precoce.

Stein et al. (2017), trazem a ideia de que o aumento das chances de sobrevivência de vítimas de PCR em ambientes não hospitalares, quando atendidas precocemente por socorristas não profissionais da saúde como policiais e bombeiros, devidamente treinados e familiarizados com o DEA.

Outro exemplo da importância do treinamento para utilizar o DEA pode ser dado pela pesquisa de Malta Hansen $e t$ al. (2017), ao afirmarem que muitos pacientes que sofrem uma parada cardíaca fora do hospital não receberão intervenção de outras pessoas, apesar do amplo treinamento em RCP e da disseminação do DEA. Continuando sua abordagem, Malta Hansen et al. (2017), citam as diretrizes preconizadas pelo Institute of Medicine, pelas diretrizes de ressuscitação e pela American Heart Association, que dão conta da necessidade de haver uma compreensão mais profunda dos fatores que permitem que as pessoas leigas tentem realizar manobras relacionadas com o uso de RCP e DEA.

Desse modo, Carvalho et al. (2020) e Maia et al. (2020), apontam para o cenário de que é necessário capacitar a população para agir em situações de emergência, em especial numa PCR, pois muitas vezes o leigo não executa as manobras de RCP por desconhecimento ou medo de realizar algo errado.

A pesquisa de Souza et al. (2020), é outro estudo que se coaduna com o cenário anterior, ao concluírem em sua pesquisa que aproximadamente metade dos leigos avaliados sabem identificar a PCR e proceder condutas adequadas como chamar o socorro especializado bem como o local em que se deve fazer as compressões no tórax. Entretanto apresentam saberes limitados que podem comprometer o prognóstico das vítimas, especialmente quanto as iniciativas, a profundidade e quantidade de compressões no tórax e sobre o uso DEA.

Como se pode evidenciar, o leigo, desde que treinado, pode reconhecer e executar esta e outras manobras de SBV, por isso vários países vêm capacitando a população, haja vista os altos índices de mortes súbitas por doenças cardiovasculares, como pode ser visto nas pesquisas de Yoon et al. (2016) e Dong et al. (2020), ao elencarem a ideia de que a utilização do DEA em acessos públicos podem trazer resultados favoráveis às vítimas de paradas cardíacas fora do hospital, porém, nas duas pesquisas pode-se observar que a utilização do DEA permanece insuficiente e varia consideravelmente de acordo com a localização da paradas cardíacas fora do hospital.

Yoon et al. (2016) e Dong et al. (2020) também vislumbram a necessidade de haver a disseminação do DEA de acesso público, bem como o treinamento de SBV para o público leigo que vive no entorno desses locais, e as sim, melhorar as taxas de sobrevivência após parada cardíaca fora do hospital.

Da mesma maneira, Malta Hansen et al. (2017), afirmam que vários fatores, além do treinamento prático anterior em PCR, facilitam a instigação da pessoa leiga sobre o uso de PCR e DEA. O reconhecimento e a modificação desses fatores podem aumentar as taxas de sobrevivência em casos PCR de espectadores leigos e a sobrevida do paciente após uma parada cardíaca fora do hospital. Carvalho et al. (2020) mostraram em seu estudo que o conhecimento do leigo sobre SBV é insatisfatório, materializado no fato de $67,7 \%$ dos entrevistados não saberem o que é SBV e 61,5\% não se sentirem preparados para agir em uma situação de emergência.

Malta Hansen et al. (2017) em seu estudo investigou o que facilitou os espectadores a tentar PCR e o uso de um DEA na cena de nos casos de paradas cardíacas fora do hospital. As principais conclusões foram que, além do treinamento prático anterior em PCR, vários fatores promoveram o uso de PCR e DEA por espectadores. Isso incluiu o seguinte: conhecimento prévio de que a intervenção do espectador é crítica para melhorar a sobrevivência, não pode causar danos e que o DEA fornece 
orientação por meio de PCR; treinamento prático prévio no uso de DEA; durante a realização da PCR, trabalho em equipe, utilizando prompt de voz do DEA e máscara de ventilação, além de mostrar liderança e sentir-se moralmente obrigado a agir.

O cenário encontrado sobre a percepção do DEA por meio deste estudo representa a realidade de como a população brasileira é carente de informações sobre esse tema, visto que se pode considerar incipientes estudos atuais que tratam da utilização do DEA por leigos na literatura nacional, porém, é preciso enfatizar que o presente estudo apontou que no Brasil não existe a cultura de utilizar o DEA em locais públicos, em contrapartida, tanto na Europa como países da Ásia, principalmente o Japão e a Coréia, utilizam essa prática de forma corriqueira com a disponibilização de um DEA para uso da população. Este equipamento verifica o ritmo cardíaco e condiciona a desfibrilação em casos de fibrilação ventricular (FV) ou taquicardia ventricular sem pulso (TVSP) e, portanto, pode interromper a PCR e reorganizar o ritmo cardíaco.

Depreende-se que com a introdução do DEA em locais públicos, permitiu-se a estabelecer um elo a mais entre o leigo e a equipe de saúde, este elo consiste de: chamar precocemente ajuda, realização correta das manobras cardiopulmonar e desfibrilação cardíaca precoce com o uso do DEA, enquanto aguarda a chegada do suporte avançado de vida, ou seja, com as referidas manobras realizadas por leigos nos casos de PCR fora do ambiente hospitalar podem aumentar as chances de sobrevivência desses pacientes.

\section{Conclusão}

A pesquisa permitiu sintetizar as evidências científicas disponíveis na literatura sobre uso DEA por pessoas leigas no atendimento pré-hospitalar, no qual há fortes evidências de que o conhecimento e a atitude de iniciar de forma precoce as manobras de SBV, assim como realizar a desfibrilação por meio de DEA, aumentam a possibilidade de sobrevivência dos pacientes vítimas de PCR fora do ambiente hospitalar.

Nessa perspectiva, as pesquisas permitiram constatar ser necessário que haja uma ampliação do treinamento de pessoas leigas em relação ao uso do DEA e na identificação de um cenário de PCR fora do hospital. Foi possível verificar também nos estudos analisados que as pessoas leigas não possuem, na sua grande maioria, conhecimento teórico e iniciativas eficientes frente ao SBV no dia-a-dia.

Neste sentido, ficou evidente que esse tipo de assistência e iniciativas prestadas por pessoas leigas muitas das vezes são inadequadas, em função da insegurança, da demora na identificação da PCR e nas ações básicas de socorro, por isso, vislumbra-se a necessidade que se crie a cultura de treinar pessoas leigas para o enfrentamento dessas demandas e possivelmente aumentar a chance de sobrevivência de uma vítima em PCR fora do ambiente hospitalar.

Assim, este estudo reforça a necessidade de ampliar as pesquisas a fim de que se possa fomentar a ideia de que há a necessidade da implantação de uma política pública no Brasil visando a implantação do DEA em lugares públicos, haja vista, que ficou evidente que países como China, Japão e EUA possuem uma política clara sobre a utilização do DEA em espaços públicos fora do contexto hospitalar e por essa prática conseguiram diminuir os óbitos relacionados com as paradas cardiorrespiratórias.

Por fim, pode-se afirmar que os objetivos da pesquisa foram alcançados, na medida em que foi possível evidenciar que o uso do DEA por pessoas leigas pode contribuir com a sobrevivência das vítimas de paradas cardiorrespiratórias fora do ambiente hospitalar, entretanto, ficou evidente a necessidade de haver conhecimento prévio da importância da intervenção de pessoas leigas, no que tange a intervir de forma correta nestes cenários.

Sugere-se que pesquisas futuras abordando questões relacionadas com a importância de oferecer Cursos de treinamento no manuseio de DEAs. Por isso, entende-se que se mostra de grande relevância promover a capacitação da população leiga em SBV e a disponibilização do DEA em locais estratégicos de acesso à população. Outra sugestão que se faz para estudos futuros é abordar se os Cursos de treinamento em DEA poderão contribuir não só para um aumento da 
sobrevivência imediata da vítima de PCR em ambiente pré- hospitalar, como também para uma melhor qualidade de vida das pessoas que sobrevivem a esse evento quando atendidas precocemente.

\section{Referências}

Carvalho, L. R. de., Ferreira, R. B. S., Rios, M. A., Fonseca, E. de O. S., \& Guimarães, Cláudia Franco. (2020). Fatores associados ao conhecimento de pessoas leigas sobre suporte básico de vida. Enfermería Actual de Costa Rica, (38), 163-178. https://dx.doi.org/10.15517/revenf.v0i38.39087

Delgado, R. C., Ureña, C. N., Fernández, A. S., Alonso, C. R., \& González, P. A. (2018). Utilización de los desfibriladores externos automáticos de uso público en el Principado de Asturias durante el periodo 2012-2014. Emergencias, v. 30, p. 00-00.

Delhomme, C., Njeim, M., Varlet, E., Pechmajou, L., Benameur, N., Cassan, P., Derkenne, C., Jost, D., Lamhaut, L., Marijon, E., Jouven, X., \& Karam, N. (2019). Automated external defibrillator use in out-of-hospital cardiac arrest: Current limitations and solutions. Archives of cardiovascular diseases, 112(3), 217-222. https://doi.org/10.1016/j.acvd.2018.11.001

Dong, X. J., Zhang, L., Yu, Y. L., Shi, S. X., Yang, X. C., Zhang, X. Q., Tian, S., Myklebust, H., Li, G. H., \& Zheng, Z. J. (2020). The general public's ability to operate automated external defibrillator: A controlled simulation study. World journal of emergency medicine, 11(4), 238-245. https://doi.org/10.5847/wjem.j.1920-8642.2020.04.006

Ferreira, M., Costa, R., \& Menezes, R. (2014). O Desfibrilador Externo Automático No Suporte Básico De Vida. Revista Enfermagem Contemporânea, 3(1). doi:http://dx.doi.org/10.17267/2317-3378rec.v3i1.334

Figueiredo, F. S. F., Rodrigues, T. F. C. da S., Rêgo, A. da S., Andrade, L. de., Oliveira, R. R. de., \& Radovanovic, C. A. T. (2020). Distribuição e autocorrelação espacial das internações por doenças cardiovasculares em adultos no Brasil. Revista Gaúcha de Enfermagem, 41, e20190314. Epub June 12, 2020. https://dx.doi.org/10.1590/1983-1447.2020.20190314

Freitas, J. R., \& Péllenz, D. C. (2018). Parada cardiorrespiratória e atuação do profissional enfermeiro. Rev. Saberes UNIJIPA, 8(1), 74-84.

Gonzalez, M. M. et al. (2013). I Diretriz de Ressuscitação Cardiopulmonar e Cuidados Cardiovasculares de Emergência da Sociedade Brasileira de Cardiologia. Arquivos Brasileiros de Cardiologia, 101(2, Suppl. 3), 1-221. https://doi.org/10.5935/abc.2013S006

Haliq, S. A. A., Khraisat, O. M., Kandil, M. A., Jumaan, M. A. A., Alotaibi, F. M., Alsaqabi, F. S., Alajmi, H. M., Ellouly, H. A., Al-Haliq, M. A., Alkhawaldeh, A., ALBashtawy, M., \& Abuhammad, S. H. (2019). Automated External Defibrillator Issues and Challenges in Saudi Arabia: Knowledge Assessment among Laypersons; Public Safety Perspective. Research Square. https://www.doi.org/10.21203/rs.2.16101/v1

Landa, J., \& Baldavira Ferreira, A. M. G. (2020). Transferência do Conhecimento de Suporte Básico de Vida para Leigos e Profissionais de Saúde: uma Revisão Integrativa. Revista Brasileira Multidisciplinar, 23(2Supl.), 99-114. https://doi.org/10.25061/2527-2675/ReBraM/2020.v23i2Supl..810

Maia, S. R. T., Lemos, A. M., Frutuoso, M. S., \& Júnior, C. W. M. R. (2020). Conhecimento dos leigos acerca da ressuscitação cardiopulmonar em pacientes adultos no Brasil. Brazilian Journal of Development, 6(5), 28933-28948. https://doi.org/10.34117/bjdv6n5-370

Malta Hansen, C., Rosenkranz, S. M., Folke, F., Zinckernagel, L., Tjørnhøj-Thomsen, T., Torp-Pedersen, C., Sondergaard, K. B., Nichol, G., \& Hulvej Rod, M. (2017). Lay Bystanders' Perspectives on What Facilitates Cardiopulmonary Resuscitation and Use of Automated External Defibrillators in Real Cardiac Arrests. Journal of the American Heart Association, 6(3), e004572. https://doi.org/10.1161/JAHA.116.004572

Mendes, K. D. S., Silveira, R. C. de C. P., \& Galvão, C. M. (2008). Revisão integrativa: método de pesquisa para a incorporação de evidências na saúde e na enfermagem. Texto \& Contexto - Enfermagem, 17(4), 758-764. https://doi.org/10.1590/S0104-07072008000400018

Merchant, R. M., Topjian, Alexis A., Panchal, Ashish R., Cheng Adam, A. K., Berg, K. M., Lavonas E. J., \& Magid, D. J. (2020). Part 1: Executive Summary: 2020 American Heart Association Guidelines for Cardiopulmonary Resuscitation and 8Emergency Cardiovascular Care. Circulation. 142(16)_Suppl_2, S337-S357.https://doi.org/10.1161/CIR.0000000000000918

Neto, J. A. C., Brum, I. V., Pereira, D. R., Santos, L. G., Moraes, S. L. de., \& Ferreira, R. E. (2016). Basic Life Support Knowledge and Interest Among Laypeople. International Journal of Cardiovascular Sciences, 29 (6), 443-452. http://www.dx.doi.org/10.5935/2359-4802.20160064

Nogueira, M. de A., et al. (2020). Métodos de treinamento de suporte básico de vida na educação de enfermagem: uma revisão integrativa da literatura. Journal of Advanced Engineering Research and Science, 7. 120-127. https://dx.doi.org/10.22161/ijaers.75.17

Oliveira, S. F. G., Moreira, S. M. B. P., Vieira, L. L., \& Gardengh, G. (2008). Conhecimento de parada cardiorrespiratória dos profissionais de saúde em um hospital público: estudo transversal. Revista Pesquisa em Fisioterapia, 8, (1), 101-109.

Pivati, I. R., Silva, J. E., \& Santos, M. V. dos. (2019). Uso do desfibrilador externo automático (DEA) por leigos qual a realidade e dificuldades enfrentadas. Revista Científica UMC, 4 (3).

Pollack, R. A., Brown, S. P., Rea, T., Aufderheide, T., Barbic, D., Buick, J. E., Christenson, J., Idris, A. H., Jasti, J., Kampp, M., Kudenchuk, P., May, S., Muhr, M., Nichol, G., Ornato, J. P., Sopko, G., Vaillancourt, C., Morrison, L., \& Weisfeldt, M. (2018). Impact of bystander automated external defibrillator use on survival and functional outcomes in shockable observed public cardiac arrests. Circulation, 137, (20), $2104-2113$.

Resende, R. T., Barbosa, A. C. S., Luiz, F. S., dos Santos, K. B., Frank, D. B. P., Motta, D. de S., Tony, A. C. C., \& Carbogim, F. da C. (2019) . Conhecimento dos acadêmicos de enfermagem sobre suporte básico de vida. Rev. enfermagem. UFPE on line, 13, (5), 1231 -1236. 
Santos, I. S. dos., Fonseca, J. R. F. da., Siqueira, T. M., Souza, N. da C. de., Albuquerque, N. R. de., Chaves, A. L. dos S., \& Silva, A. M. da. (2018, maio/junho). Ressuscitação Cardiopulmonar Para Leigos: Conhecer para Aplicar. Anais do $13^{\circ}$ Congresso Internacional da Rede Unida. Manaus, AM, BRASIL, 13 .

Santos, C. M. da C., Pimenta, C. A. de M., \& Nobre, M. R. C. (2007). A estratégia PICO para a construção da pergunta de pesquisa e busca de evidências. Revista Latino-Americana de Enfermagem, 15(3), 508-511. https://doi.org/10.1590/S0104-11692007000300023

Silva, B. T. G. da., Andrade, E. da S., Paiva, R. de M., Lima Neto, A. V. de., Silva, H. L. L. da., \& Santos, W. N. dos. (2019). The knowledge of health academics with regards to cardiopulmonary resuscitation in basic life support / Conhecimento de acadêmicos da saúde sobre ressuscitação cardiopulmonar no suporte básico de vida. Revista de Pesquisa: Cuidado é Fundamental Online, 11(4), 957-961. http://dx.doi.org/10.9789/2175-5361.2019.v11i4.957-961

Silva, B. K. M. da., Kennia, R. T., Ansaloni, L. V. S., Moraes, P. H. A. de., Oliveira, R. A. de., \& Matias, P. R. da S. (2020). O conhecimento acerca do suporte básico de vida: uma revisão integrativa, Brazilian Journal of Development, 6 (9), 72021-72039.

Soares, C. B., Hoga, L. A. K., Peduzzi, M., Sangaleti, C., Yonekura, T., \& Silva, D. R. A. D. (2014). Integrative Review: Concepts And Methods Used In Nursing. Revista da Escola de Enfermagem da USP, 48(2), 335-345. https://doi.org/10.1590/S0080-6234201400002000020

Souza, R. P de., Zanin, L., Motta, R. H. L., Ramacciato, J. C., \& Flório F. M. (2020). Parada Cardiorrespiratória: Avaliação Teórica Das Condutas Emergenciais De Pessoas Leigas. Revista Norte Mineira de enfermagem, 9 (1):29-39. https://doi.org/10.46551/rnm23173092202090104

Souza, M. T. de., Silva, M. D. da., \& Carvalho, R. de. (2010). Revisão integrativa: o que é e como fazer. Einstein (São Paulo), 8(1), 102-106. https://doi.org/10.1590/s1679-45082010rw1134

Stein, P., Spahn, G. H., Müller, S., Zollinger, A., Baulig, W., Brüesch, M., Seifert, B., \& Spahn, D. R. (2017). Impact of city police layperson education and equipment with automatic external defibrillators on patient outcome after out of hospital cardiac arrest. RESUSCITATION, 118, 27-34. https://doi.org/10.1016/j.resuscitation.2017.06.017

Wang, Tsung-Hsi., Wu, Hsi-Wen., Hou, Peter C., \& Tseng, Hao-Jui. (2018). The utilization of automated external defibrillators in Taiwan. Journal of the Formosan Medical Association, 118(1), 148-151.

Weisfeldt, M. L., \& Pollack, R. A. (2017). Public access defibrillation: is this making any difference? Controversial issues in resuscitation from cardiac arrest. Cardiac electrophysiology clinics, 9 (4), 551-557https://doi.org/10.1016/j.ccep.2017.07.006 .

Welch, V., Petticrew, M., Petkovic, J., Moher, D., Waters, E., White, H., \& Tugwell, P., Grupo PRISMA-Equity Bellagio. (2016). Extending the PRISMA statement to equity-focused systematic reviews (PRISMA-E 2012): explanation and elaboration. Journal of clinical epidemiology,70, p. 68-89, 2016. https://doi.org/10.1016/j.jclinepi.2015.09.001

Yoon, C. G., Jeong, J., Kwon, I. H., \& Lee, J. H. (2016). Availability and use of public access defibrillators in Busan Metropolitan City, South Korea. SpringerPlus, 5(1), 1524. https://doi.org/10.1186/s40064-016-3201-6

Yonekura, T., Quintans, J. R., Soares, C. B., \& Negri Filho, A. A. de. (2019). Revisão realista como metodologia para utilização de evidências em políticas de saúde: uma revisão integrativa. Revista da Escola de Enfermagem da USP, 53, e03515. Epub December 02, 2019. https://doi.org/10.1590/s1980$220 \times 2018037703515$ 